\title{
Genetic variability and virulence of Meloidogyne incognita populations from Brazil to resistant cotton genotypes
}

\author{
Esdras Henrique da Silva • Vanessa da Silva Mattos • Cleber Furlaneto • Marc Giband • \\ Paulo Augusto Vianna Barroso • Antônio Williams Moita • Aldemiro Jorge-Junior • \\ Valdir Ribeiro Correa • Philippe Castagnone-Sereno • \\ Regina Maria Dechechi Gomes Carneiro
}

Accepted: 2 January 2014 / Published online: 19 January 2014

(C) KNPV 2014

\begin{abstract}
The root-knot nematode Meloidogyne incognita is widely distributed and a major pathogen of cotton (Gossypium spp.) worldwide. The objectives of this study were to assess the genetic variability and aggressiveness of Brazilian populations of $M$. incognita in cotton. Five populations of $M$. incognita and one isolate
\end{abstract}

Esdras Henrique da Silva and Vanessa da Silva Mattos contributed equally to this work.

E. H. da Silva • V. da Silva Mattos - A. Jorge-Junior •

V. R. Correa $\cdot$ R. M. D. G. Carneiro $(\bowtie)$

Embrapa Recursos Genéticos e Biotecnologia,

Brasília, DF 70849-970, Brazil

e-mail: regina.carneiro@embrapa.br

E. H. da Silva • V. da Silva Mattos • C. Furlaneto •

V. R. Correa

Departamento de Fitopatologia, Universidade de Brasília,

Brasília, DF 70910-900, Brazil

\section{P. A. V. Barroso}

Núcleo Cerrado da Embrapa Algodão,

Santo Antônio de Goiás, GO 75375-000, Brazil

\section{A. W. Moita}

Embrapa- Centro Nacional de Pesquisa em Hortaliças,

Brasília, DF 70359-970, Brazil

\section{Giband}

Cirad, UMR AGAP,

Avenue Agropolis, 34398 Montpellier, France

P. Castagnone-Sereno

INRA-UMR 1355, UNS, CNRS-UMR 7254, Institut Sophia

Agrobiotech,

400 route des Chappes, BP167, 06903 Sophia Antipolis,

France of $M$. enterolobii (outgroup) were used in the molecular analysis. Our results showed that only $2.7 \%$ of the RAPD and AFLP fragments were polymorphic. Despite the existence of two races (races 3 and 4) and two esterase phenotypes (I1 and I2), a low genetic variability among populations was observed, which might be due to the mitotic parthenogenetic mode of reproduction of this pathogen. The aggressiveness/virulence among populations towards different cotton genotypes was also studied. None of the populations was virulent to the resistant cotton genotypes M-315 RNR, TX-25, CIR1343, Wild Mexican Jack Jones and CIR1348 (reproduction factor $<1$ ). Two populations of M. incognita from the states of Mato Grosso do Sul and Parana (Umuarama) (races 4 and 3, respectively) were highly aggressive to the susceptible control FM966 and virulent to the accessions LA- 887 and Clevewilt- 6 that showed moderate resistance to other populations tested.

Keywords AFLP·Gossypium spp. RAPD · RKN management $\cdot$ Resistance $\cdot$ Pathogenicity

\section{Introduction}

The root-knot nematode (RKN) Meloidogyne incognita (Kofoid \& White) Chitwood 1949 is widespread and a major pathogen in cotton (Gossypium hirsutum L) production areas worldwide (Starr et al. 2005), causing direct damage and increasing the incidence and severity of other root diseases, in particular Fusarium wilt, caused by the fungus Fusarium oxysporum f. sp. 
vasinfectum (Atk.) Snyd. Hans (Jeffers and Roberts 1993; Abawi and Chen 1998). RKN host races 3 and 4 are able to parasitize cotton in the USA (Veech and Starr 1986) and in Brazil (M. Inomoto, personal communication).

Efficient RKN management may be achieved through the use of resistant varieties which help control the disease and maintain crop yield, while decreasing nematode populations in the soil and protecting the following crops (Ruano et al. 1997; Davis and Kemerait 2009). Nevertheless, repeated exposure of nematodes to resistant varieties may induce the emergence of resistance-breaking isolates, which may occur in a few generations (Netscher 1977; Janssen et al. 1998). In addition to the development of virulence under selective conditions, naturally resistance-breaking field populations, not exposed previously to resistant cultivars, have been observed (Roberts and Thomason 1989). The parthenogenetic RKN species exhibit a high capacity to respond to environmental selection, and their ability to overcome plant resistance genes has been demonstrated (Roberts 1995; Castagnone-Sereno 2002; Castagnone-Sereno et al. 2007). Virulence selection in nematode populations after successive expositions to resistant crop varieties has been reported especially against the $M i$ resistance gene in tomato (Roberts $1992,1995)$ or cowpea genotypes with the $R k$ resistance gene (Roberts et al. 1995). In cotton, selection of isolates with increased reproduction on resistant varieties has been demonstrated (Ogallo et al. 1997). Resistance based on the deployment of a single or a few genes may be more prone to resistance break-down. At present, cotton breeding for RKN resistance relies on a limited number of sources of resistance, with only a small number of genes involved (Robinson et al. 2001; McPherson et al. 2004; Starr et al. 2010). Furthermore, variability in the virulence of RKN isolates on resistant cotton genotypes has been demonstrated (Elliott et al. 1998; Zhou et al. 2000; Anwar and McKenry 2007). These observations point out to the need for identifying novel sources of resistance and increasing the number of useful genes. They also point out to the need for better documenting the extent of variability of the aggressiveness or virulence of RKN populations from different cotton-producing regions towards resistant and tolerant genotypes.

The development of molecular techniques has opened new prospects for species identification and for the study of intraspecific variability of RKNs (Currant et al. 1986; Castagnone-Sereno et al. 1991, 1993).
Neutral molecular markers, such as RAPD, AFLP and ISSR, have been used to analyze the genetic diversity of Meloidogyne species (Castagnone-Sereno et al. 1994; Blok et al. 1997; Semblat et al. 1998; Randig et al. 2002; Carneiro et al. 2004, 2008; Fargette et al. 2005; Muniz et al. 2008; Santos et al. 2012). In cotton, studies on the variability of aggressiveness or virulence among RKN populations are still scarce (Elliott et al. 1998; Zhou et al. 2000; Anwar and McKenry 2007), and no reports are available on the extent of the genetic variability of M. incognita cotton isolates. We have recently identified accessions of Gossypium spp. that were highly resistant to a Brazilian isolate of $M$. incognita race 3 from Londrina, Paraná State (Mota et al. 2013), that represent novel sources of resistance to RKNs in cotton. In the present study, we show that despite having a low level of genetic diversity, $M$. incognita populations from the major cotton-producing regions in Brazil show variability in virulence towards moderately resistant cotton genotypes. We also show that none of the nematode populations studied were able to reproduce on the highly resistant accessions identified in our previous study, confirming their usefulness as a source of durable resistance to RKN.

\section{Materials and methods}

Identification of nematode species and races

Five populations of $M$. incognita pathogenic to cotton (Gossypium spp.) were obtained from cotton fields from different regions in Brazil (Table 1). They were specifically identified using esterase (Est) and malate dehydrogenase (MDH) phenotypes according to a standard procedure (Carneiro and Almeida 2001). Races of M. incognita were determined according to Hartman and Sasser (1985). A population of M. enterolobii was used as an outgroup in the diversity analysis.

Egg extraction and DNA preparation

The extraction of eggs for DNA purification was done according to Carneiro et al. (2004). Total genomic DNA was extracted from $\sim 200$ to $300 \mu$ l of nematode eggs that had been stored at $-80{ }^{\circ} \mathrm{C}$ before use, as described by Randig et al. (2002). Isolated DNA was re-suspended in Milli-Q water, quantified in a $1 \%$ agarose gel and stored at $-20{ }^{\circ} \mathrm{C}$. 
Table 1 List of Meloidogyne spp. populations and their isozyme phenotypes from different regions in Brazil used in this study

${ }^{a}$ Est esterase, $M d h$ malate dehydrogenase

${ }^{\mathrm{b}}$ Brazilian States

\begin{tabular}{lllll}
\hline Species/Race & Population code & Geographic origin & \multicolumn{2}{c}{ Phenotypes $^{\mathrm{b}}$} \\
\cline { 4 - 5 } & & & Est & Mdh \\
\hline 1)M. incognita Race 4 & MT- R4 & Campo Verde - MT & I2 & N1 \\
2)M. incognita Race 3 & PR-R3 (LON) & Londrina - PR & I1 & N1 \\
3)M. incognita Race 3 & PR-R3 (UMU) & Umuarama - PR & I2 & N1 \\
4)M. incognita Race 3 & MTS-R3 & Dourados - MS & I2 & N1 \\
5)M. incognita Race 3 & BA-R3 & Luís Eduardo Magalhães - BA & I2 & N1 \\
6)M. enterolobii & MENT & Petrolina - PE & VS1-S1 & N1 \\
\hline
\end{tabular}

Random amplified polymorphic DNA (RAPD) analysis

The RAPD reactions were performed in a volume of $13 \mu$ containing 9 ng of genomic DNA, using the PCR conditions described by Carneiro et al. (2008). The following 22 random 10-mer oligonucleotide primers (Operon Technologies, Alameda-Ca, USA) were used in the analysis, including A18, B01, B06, B12, C09, D05, D13, D20, E18, G03, G05, J10, J19, K04, K07, K16, L08, M20, N10, P02, R04 and R07. Amplification products were separated by agarose gel electrophoresis as previously described (Randig et al. 2002).

Inter-simple sequence repeat (ISSR) analysis

The amplification reactions were performed in a $13 \mu \mathrm{l}$ volume containing $9 \mathrm{ng}$ of genomic DNA, using the PCR conditions described by Carneiro et al. (2008). The following 9 ISSR primers (Integrated DNA Technologies, Belo Horizonte, Brazil) were used: $(\mathrm{CA})_{8},(\mathrm{AC})_{8}$, $(\mathrm{CCA})_{5},(\mathrm{CA})_{8} \mathrm{CTCT} \mathrm{T},(\mathrm{GT})_{8} \mathrm{YA},(\mathrm{GACA})_{4}$ and $(\mathrm{GTC})_{6}$. Amplification products were separated by agarose gel electrophoresis as previously described (Randig et al. 2002).

Amplified fragment length polymorphism (AFLP) analysis

For each sample, approximately $1 \mu \mathrm{g}$ of genomic DNA was digested with EcoRI and ligated to EcoRI adaptors in a $20 \mu \mathrm{l}$ volume and incubated overnight at $37{ }^{\circ} \mathrm{C}$ (Suazo and Hall 1999). The digestion-ligation reactions were diluted with Tris EDTA buffer to a final volume of $200 \mu \mathrm{l}$ and stored at $-20^{\circ} \mathrm{C}$. A series of thirteen 19-mer primers (Integrated DNA Technologies) were used, consisting of the EcoRI adapter core sequence GACT
GCGTACCAATTCAGT plus the 3' selective nucleotides AGT, ACT, ATT, GGC, CAG, TGG, CCT, ACC, GCC, CGA, CTC, CAT and CCG. Amplification products were separated by electrophoresis as previously described (Semblat et al. 1998).

Phylogenetic analysis

For each type of marker, amplified bands were scored as present or absent from the digitized photographs of the gels, and DNA fingerprints of the populations were converted into a binary matrix. Phylogenetic reconstruction was performed using the Unweighted Pair Group Method with Arithmetic Mean (UPGMA) algorithm implemented in PAUP* version $4 b 10$ (Swofford 2002). The data were assumed to be unordered with no a priori weighting. For all analyses, 1,000 bootstrap replicates were performed to test the node support of the generated trees. Moreover, as the AFLP and RAPD markers amplified here could reasonably be considered as independent characters, the datasets that exhibited polymorphism between populations were combined to run a global UPGMA analysis, according to the total-evidence approach (Huelsenbeck et al. 1996), using the same computer settings as in the two individual analyses. A population of $M$. enterelobii was used as an outgroup. The correlation among genetic and geographic distance matrices were estimated with Mantel test with 10,000 permutations using IBDWS program (Jensen et al. 2005).

\section{Gossypium genotypes}

G. hirsutum and G. barbadense accessions used in this study (Table 2) were obtained from Cirad's or Embrapa's germplasm collections. These genotypes have been previously tested and were shown to be 
Table 2 Description of Gossypium spp. accessions used in the study

\begin{tabular}{lll}
\hline Accession name & Species & Origin-accession number \\
\hline CIR1348 & G. barbadense race barbadense & Peru-wild accession; Cirad accession $\mathrm{n}^{\circ}$ CIR1348 \\
Clevewilt-6 & G. hirsutum & USA-Obsolete cultivar with moderate resistance to RKN \\
Fibermax966 (FM966) & G. hirsutum & Australia - Commercial variety \\
LA-887 & G. hirsutum & USA-Obsolete cultivar with resistance to RKN \\
M-315 RNR & G. hirsutum & USA-Breeding line highly resistant to RKN \\
TX-25 & G. hirsutum race punctatum & Mexico-wild accession; \\
& & NPGS PI n ${ }^{\circ}$ 154035 \\
CIR1343 & G. barbadense race barbadense & Peru-wild accession; Cirad accession $\mathrm{n}^{\circ}$ CIR1343 \\
Wild Mexican Jack Jones (WMJ) & G. hirsutum & Mexico-wild accession; USDA accession TX-2516, \\
& & NPGS PI n ${ }^{\circ}$ 593649 \\
\hline
\end{tabular}

${ }^{\text {a }}$ Susceptible to Meloidogyne incognita

moderately to highly resistant to a local population of M. incognita race 3 (Mota et al. 2013). G. hirsutum cv. FiberMax966 (FM966) was used as a susceptible check, while $G$. hirsutum breeding line M-315 RNR was used as a resistant control.

Nematode inoculum

Four populations of M. incognita race 3 and one population of race 4 collected in different States of Brazil (Table 1) were used in this study. Prior to inoculation, the populations were multiplied on tomato (Solanum lycopersicum L., cv. Santa Clara) for 3 months under greenhouse conditions. Eggs were extracted from infected roots using $0.5 \% \mathrm{NaOCl}$ according to Boneti and Ferraz (1981). Counting was done using a light microscope and Peter's slides.

Evaluation of nematode resistance

Eight plants of each genotype were grown in pots $(20 \times$ $15 \mathrm{~cm}, \mathrm{~h} \times \mathrm{w})$ filled with a mixture $(1: 1)$ of autoclaved soil and Bioplant ${ }^{\circledR}$ compost and maintained at $25-30{ }^{\circ} \mathrm{C}$ under greenhouse. Thirty days after seedling emergence, pots were inoculated with 10,000 eggs of $M$. incognita by pipetting nematode suspension around the stem base. Plants were arranged in a randomized block design with eight replications, and were watered and fertilized as needed. Four months after inoculation, the root systems were rinsed under tap water and weighed. Roots were stained with Phloxine B and evaluated for gall and egg mass numbers (galling index-GI or egg-mass indexEMI), using a 0-5 scale where 0: no galls or egg masses;
1: 1-2 galls or egg masses; $2: 3-10$ galls or egg masses; 3: 11-30 galls or egg masses; 4: 31-100 galls or egg masses; and 5: $>100$ galls or egg masses per root system (Hartman and Sasser 1985).

Eggs were extracted using a modified extraction method according to Boneti and Ferraz (1981), using $1 \% \mathrm{NaOCl}$. The reproduction factor (RF) was calculated as $\mathrm{RF}=\mathrm{FP} / \mathrm{IP}$, where $\mathrm{FP}=$ final nematode population and IP $=$ initial nematode population $(\mathrm{IP}=10,000)$. The average RF was transformed as $\log (\mathrm{x}+1)$, submitted to analysis of variance and the means separated using Scott-Knot's test $(P<0.05)$. Accessions were classified as susceptible (S), moderately resistant (MR), or resistant $(\mathrm{R})$ according to the analysis of variance, and to concepts by Oostenbrink (1966) and Starr and Mercer (2009). The experiment was repeated once with datasets analyzed as individual runs.

\section{Results}

Characterization of nematode populations

Two phenotypes for EST activity were recognised among the five $M$. incognita populations from cotton (Table 1). The phenotype I1 with one band (Rm: 1.0) was detected in the population from Londrina while the phenotype I2 with two bands, a major band ( $R m$ 1.1) and a minor band ( $R m$ 1.2), was detected in the other four populations. No correlation was observed between EST phenotype and races. The MDH N1 phenotype (Rm 1.0) was detected in all populations studied. 
The five $M$. incognita populations reproduced on tomato 'Rutgers', watermelon 'Charleston Gray', pepper 'California Wonder' and on cotton 'Deltapine 61', however they varied in their response to resistant tobacco 'NC95'; population 1 reproduced on tobacco and was classified as belonging to race 4 , while populations 2, 3, 4 and 5 did not, and were assigned to race 3 .

\section{Genetic diversity}

All three types of markers produced amplification products. Examples for RAPD and AFLP are shown in Fig. 1. There were a total of 331 amplified fragments for $M$. incognita populations. The number of fragments ranged from 1-11/population and varied in size from ca. 200 to $2,500 \mathrm{bp}$ for RAPDs; $1-10$ /population and 150 to $2,500 \mathrm{bp}$ for ISSRs and $1-16$ /population and 180 to $2,500 \mathrm{bp}$ for AFLPs. Overall, only nine fragments $(2.7 \%)$ were polymorphic in this study. None of the nine ISSR primers tested produced polymorphic bands. The primers which revealed polymorphic fragments

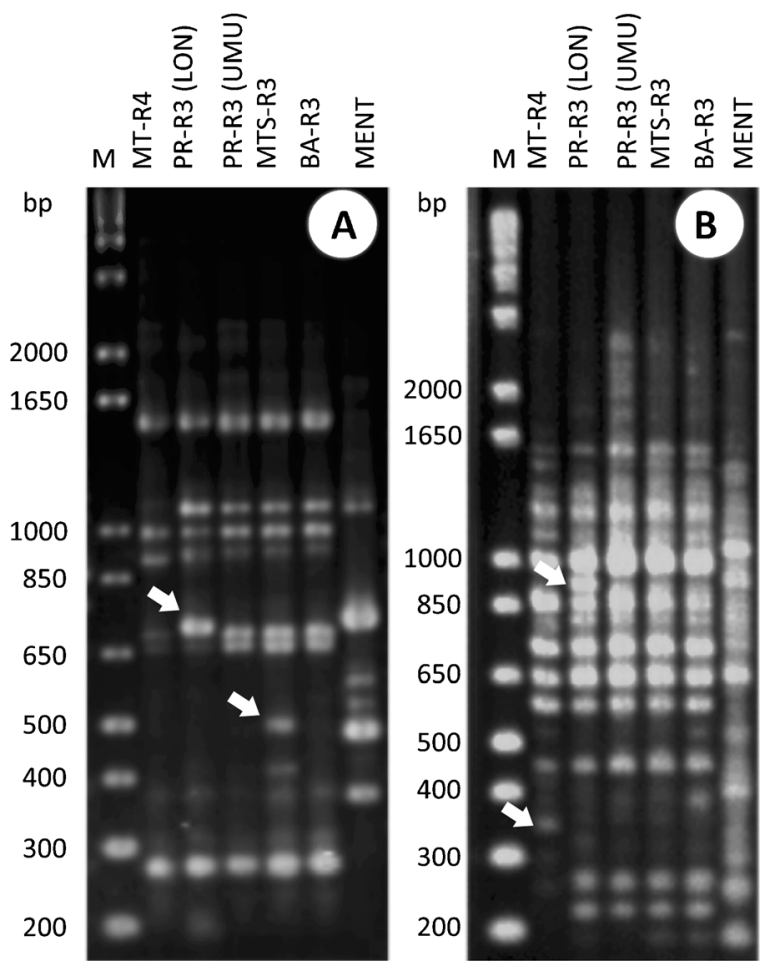

Fig. 1 Example of amplification patterns for Meloidogyne spp. populations generated with primers RAPD G05 (a) and AFLP 08 (GAC TGC GTA CCA ATT CAG T CCT) (b). Arrows indicate polymorphic bands. M, $1 \mathrm{~kb}$ DNA Plus ladder (Invitrogen). bpbase pairs. Isolate codes are described in Table 1 were the RAPD primers A18, D05, D13, D20, G05, and AFLP primers, AFLP 8 and AFLP 9.

All scorable amplified bands were recorded to build a 0-1 matrix, on which cluster analysis were done using UPGMA. The dendrogram resulting from the concatenation of RAPD and AFLP data set is shown in Fig. 2. The two populations (race 3) from Paraná state were closely related (91\% bootstrap support), however, no overall clustering of populations according to races was detected.

Diversity among different populations of M. incognita from cotton was low. A small yet significant correlation between geographic and genetic distances was observed using the Mantel test. The correlation was positive, $R=$ $0.64(p<0.05)$, meaning that populations geographically closer tend also to be genetically closely related, while populations geographically distant tended to be more genetically divergent.

Resistance of cotton accessions to M. incognita races 3 and 4

Resistance was evaluated based on three criteria: galling index, egg mass index and reproduction factor (RF). All nematode populations tested showed reduced reproduction factors $(\mathrm{RF}<0.2)$ on the resistant accessions M-315

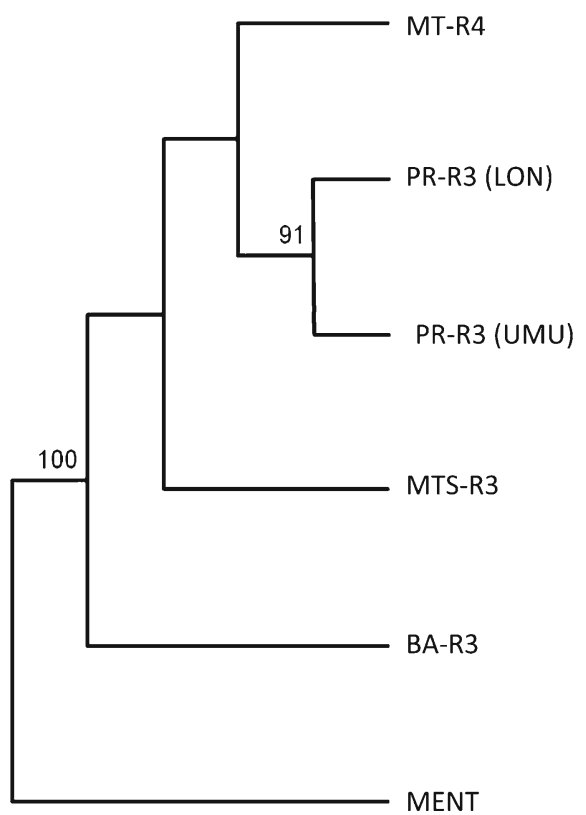

Fig. 2 Dendrogram showing the relationships of Meloidogyne spp. populations using a concatenated dataset of RAPD and AFLP. Bootstrap values $(>50 \%)$ based on 1,000 replicates. Isolate codes are described at Table 1 
RNR (resistant control), TX-25, CIR1348, CIR1343 and Wild Mexican Jack Jones (Table 3). Gall and egg mass formation were also partially suppressed on these cotton accessions (Table 4). In contrast, the susceptible control FM966 exhibited high gall and egg mass numbers, and high reproduction factors for all populations (Tables 3 and 4). The accessions Clevewilt-6 and LA887 , considered to display moderate resistance, showed intermediate RF (1.1 to 5.1) and gall/egg mass indices when challenged with populations MTS-R3, BA-R3 and PR-R3 LON (Tables 3 and 4). In contrast, they allowed high RF (19.4 to 57.6) and gall/egg mass formation when challenged with populations MT-R4 and PR-R3 UMU (Tables 3 and 4), and were considered susceptible to them.

\section{Discussion}

Despite the existence of two races (races 3 and 4) and two esterase profiles (I1 and I2), a low genetic variability was observed among Brazilian populations of M. incognita in cotton. Similar results were reported for other Meloidogyne species (Castagnone-Sereno et al. 1994; Blok et al. 1997; Randig et al. 2002; Carneiro et al. 2004; Cofcewicz et al. 2005; Santos et al. 2012), and might be related to the mitotic parthenogenetic reproduction of these species (Triantaphyllou 1985). The identification of races in RKN nematodes is important not only for the characterization of resistance, but also in the management programs in infested areas (Fassuliotis 1985; Ibrahim and Lewis 1993; Castro et al. 2003). However, although race determination is important in practice, Moens et al. (2009) recommended discontinuation of this terminology, as this concept has never been universally accepted because it measures a very restricted portion of the potential variation in parasitic variability. In our study, no relationship was observed among (host) race, enzymatic phenotypes (I1 and I2) and genetic polymorphism. These findings suggest that for $M$. incognita, races do not have a genetic determinism, which is in good agreement with previous observations (Carneiro and Cofcewicz 2008). Indeed, despite continuous efforts from several research groups, no correlation could be found between isoenzymatic or molecular infraspecific polymorphism and races in Meloidogyne species (Cenis 1993; Baum et al. 1994). Furthermore, we did not observe any correlation between race, enzymatic phenotype, genetic diversity and aggressiveness/virulence. The results obtained in this work could indicate a possible geographical and genetic relationship among populations of $M$. incognita from cotton. Similar results were observed for $M$. arenaria in different crops

Table 3 Reproduction factor (RF) of five different populations of Meloidogyne incognita races 3 and 4 on selected cotton accessions

\begin{tabular}{|c|c|c|c|c|c|}
\hline \multirow[t]{2}{*}{ Cotton accessions ${ }^{\mathrm{a}}$} & \multicolumn{5}{|c|}{ Populations ${ }^{\mathrm{c}} /$ Reaction $^{\mathrm{b}, \mathrm{d}}$} \\
\hline & MT- R4 & MTS-R3 & BA-R3 & PR-R3 (UMU) & PR-R3 (LON) \\
\hline TX-25 & $0.10 \mathrm{~b} \mathrm{R}$ & $0.03 \mathrm{~d} R$ & $0.01 \mathrm{c} \mathrm{R}$ & $0.04 \mathrm{~d} \mathrm{R}$ & 0.13 c R \\
\hline CIR 1348 & 0.09 b R & $0.05 \mathrm{~d} R$ & $0.25 \mathrm{c} \mathrm{R}$ & $0.06 \mathrm{~d} \mathrm{R}$ & $0.02 \mathrm{c} \mathrm{R}$ \\
\hline CIR1343 & $0.19 \mathrm{~b} \mathrm{R}$ & $0.07 \mathrm{~d} \mathrm{R}$ & $0.25 \mathrm{c} \mathrm{R}$ & $0.17 \mathrm{~d} \mathrm{R}$ & $0.20 \mathrm{c} \mathrm{R}$ \\
\hline Wild Mexican Jack Jones & $0.04 \mathrm{~b} \mathrm{R}$ & $0.10 \mathrm{~d} R$ & 0.24 c R & $0.60 \mathrm{~d} R$ & $0.01 \mathrm{c} \mathrm{R}$ \\
\hline Clevewilt-6 & $57.61 \mathrm{a} \mathrm{S}$ & $4.61 \mathrm{~b} \mathrm{MR}$ & $5.10 \mathrm{~b} \mathrm{MR}$ & $38.04 \mathrm{~b} \mathrm{~S}$ & $3.51 \mathrm{~b} \mathrm{MR}$ \\
\hline LA-887 & 46.75 a S & $1.69 \mathrm{c} \mathrm{MR}$ & $3.8 \mathrm{~b} \mathrm{MR}$ & 19.36 c S & $1.10 \mathrm{~b} \mathrm{MR}$ \\
\hline M-315 RNR & 0.07 b R & $0.01 \mathrm{~d} \mathrm{R}$ & $0.04 \mathrm{c} \mathrm{R}$ & $0.02 \mathrm{~d} \mathrm{R}$ & 0.04 c R \\
\hline Fibermax966 (susceptible control) & 56.51 a S & 19.12 a S & 36.71 a S & 70.69 a S & 26.25 a S \\
\hline
\end{tabular}

Coefficient of variation $(\%)=28$

${ }^{\text {a }}$ Cotton accessions are described in Table 2

${ }^{\mathrm{b}}$ Mean values ( 8 plants per accession) are transformed as $\log (\mathrm{x}+1)$. Means followed by different letters within columns are significantly different $(P<0.05)$ according to Scott-Knot's test

${ }^{\mathrm{c}}$ Mincognita populations described in Table 1

${ }^{\mathrm{d}} S$ susceptible; $M R$ moderately resistant; $R$ resistant 
Table 4 Mean galling index (GI) or egg mass index (EMI) of five different populations of Meloidogyne incognita races 3 and 4 on selected cotton accessions

\begin{tabular}{|c|c|c|c|c|c|c|c|c|c|c|}
\hline \multirow[t]{3}{*}{ Cotton accessions $^{\mathrm{a}}$} & \multicolumn{10}{|c|}{ Populations ${ }^{\mathrm{b}}$} \\
\hline & \multicolumn{2}{|c|}{ MT- R4 } & \multicolumn{2}{|c|}{ MTS-R3 } & \multicolumn{2}{|c|}{ BA-R3 } & \multicolumn{2}{|c|}{ PR-R3 (UMU) } & \multicolumn{2}{|c|}{ PR-R3 (LON) } \\
\hline & $\mathrm{GI}^{\mathrm{c}}$ & $\mathrm{EMI}^{\mathrm{c}}$ & GI & EMI & GI & EMI & GI & EMI & GI & EMI \\
\hline TX-25 & 2.7 & 0 & 0.7 & 0 & 2.1 & 0 & 1.2 & 0 & 3.0 & 0.2 \\
\hline CIR 1348 & 1.8 & 0 & 0 & 0 & 1.5 & 0 & 2.3 & 0 & 0.3 & 0 \\
\hline CIR1343 & 2.5 & 1.5 & 1.8 & 0 & 2.5 & 0 & 1.8 & 0 & 0.2 & 0 \\
\hline Wild Mexican Jack Jones & 3,2 & 0 & 1.7 & 0.8 & 1.6 & 0 & 3.3 & 0 & 0.8 & 0 \\
\hline Clevewilt-6 & 4.8 & 4.5 & 3.2 & 2.2 & 5.0 & 3.5 & 5.0 & 4.8 & 3.5 & 2.5 \\
\hline LA-887 & 5.0 & 5.0 & 3.3 & 1.5 & 2.5 & 2.5 & 4.8 & 4.8 & 2.8 & 2.5 \\
\hline M-315 RNR & 1.3 & 0 & 0.5 & 0 & 0.8 & 0 & 1.2 & 0 & 0.8 & 0 \\
\hline Fibermax966 (susceptible control) & 5.0 & 5.0 & 5.0 & 5.0 & 5.0 & 5.0 & 5.0 & 5.0 & 5.0 & 5.0 \\
\hline
\end{tabular}

${ }^{\text {a }}$ Cotton accessions are described in Table 2

${ }^{\mathrm{b}}$ M. incognita populations described in Table 1

${ }^{\mathrm{c}}$ Mean values (8 plants per accession) of GI or EMI. 0: no gall or egg-mass, 1: 1-2 galls or egg-masses, 2: 3-10 galls or egg-masses, 3: 1130 galls or egg-masses, 4: 31-100 galls or egg-masses, and 5:>100 galls or egg-masses per root system (Hartman and Sasser 1985)

(Carneiro et al. 2008). However, it would be necessary to confirm this trend by analyzing a larger set of cotton nematode populations from other continents.

The physiological variation among RKN species or population can be expressed in the plant-nematode interaction on three levels: (non)-host status, aggressiveness and virulence. Aggressiveness reflects the reproductive ability, as measured by the RF of nematodes on a susceptible host, whereas virulence is the ability to reproduce on a resistant host (Hussey and Janssen 2002). In this study, considering accession FM966 as the susceptible control, the population PR-R3 (UMU) was the most aggressive, followed by MT-R4. In our assays, populations MT-R4 and PR-R3 (UMU) overcame the resistance of Clevewilt- 6 and LA-887, two accessions that are usually considered as moderately resistant to M. incognita (McClure et al. 1974; Robinson et al. 1997). The population MT-R4 (race 4) was more aggressive than population PR-R3 (UMU) (race 3), considering the higher reproduction factors observed in the moderately resistant cultivars (Clevewilt-6 and LA-887).

None of the five populations of $M$.incognita collected in different cotton fields were able to cause severe galling, produce high numbers of egg-masses, or reproduce at high rates on the resistant cotton accessions TX25, M-315 RNR, CIR1348, CIR1343, and Wild Mexican Jack Jones. These data suggest that the resistance in these cotton accessions will have broad applicability and it will be effective in the main cottonproducing regions of Brazil.

Resistance based on a few genes may impose a selection pressure on nematode populations and hasten the selection of virulent isolates (Janssen et al. 1990), as has been observed in tomato with the $\mathrm{Mi}$ resistance gene (Riggs and Winstead 1959), in wild potato with the gene Rmc2 (Janssen et al. 1998) or in coffee with the Mex-1 gene (Muniz et al. 2009). The high level of resistance to M. incognita found in the cotton breeding line M-315 RNR and in other lines derived from the same Auburn 634 RNR source has not been transferred to superior varieties. This resistance is inherited as two major genes, presumably one from Clevewilt- 6 and other from Wild Mexico Jack Jones (McPherson et al. 2004; Starr et al. 2010). Clevewilt-6 has one recessive resistance gene that confers moderate resistance to $M$. incognita (Kirkpatrick and Rothrock 2001), and it is also believed to be the source of resistance in LA-887 (Jones et al. 1990). The same resistance allele is present in some of the varieties cultivated in Brazil (P. Barroso, unpublished results), pointing out to the need for more efficient resistance gene combinations. All the populations tested were avirulent to M-315 RNR, which harbours a second gene in addition to that originating from Clevewilt-6. The resistance present in Wild Mexican Jack Jones has never been deployed in varieties 
cultivated in Brazil. This accession interestingly shows a high level of resistance to all populations tested, even to the most virulent ones. The other accessions demonstrating high levels of resistance to all populations tested, TX-25, CIR1348 and CIR1343, also constitute interesting sources of resistance that have, to the best of our knowledge, never been deployed in cultivated varieties. In the present study, we have shown that these sources of resistance could have a large adaptability. Studies are underway to determine whether the resistant gene(s) and allele(s) in TX-25, CIR1348 and CIR1343 are different from those present in Auburn 634 RNR and in the derived germplasm. The identification and full characterization of novel sources of resistance that can be pyramided and/or rotated is an important goal towards the effective and durable management of RKN in cotton.

Acknowledgments This work was supported by Conselho Nacional de Desenvolvimento Científico e Tecnológico (CNPq), EMBRAPA-Recursos Genéticos e Biotecnologia and EMBRAPA - Algodão. E.H. Silva and V.S. Mattos thank CNPq for their scholarships.

\section{References}

Abawi, G. S., \& Chen, J. (1998). Concomitant pathogen and pest interactions. In K. R. Barker, G. A. Pederson, \& G. L. Windham (Eds.), Plant and nematode interactions (pp. 135-158). Wisconsin: American Society of Agronomy.

Anwar, S. A., \& McKenry, M. V. (2007). Variability in reproduction of Meloidogyne incognita on six cultivars of cotton. Journal of Nematology, 39, 105-110.

Baum, T. J., Gresshoff, P. M., Lewis, S. A., \& Dean, R. A. (1994). Characterization and phylogenetic analysis of 4 root-knot nematode species using DNA amplification fingerprinting and automated polyacrylamide-gel electrophoresis. Molecular Plant-Microbe Interactions, 7, 39-47.

Blok, V. C., Phillips, M. S., Mcnicol, J. W., \& Fargette, M. (1997). Genetic variation in tropical Meloidogyne spp. as shown by RAPDs. Fundamental and Applied Nematology, 20, 127133.

Boneti, J. I. S., \& Ferraz, S. (1981). Modificação do método de Hussey \& Barker para extração de ovos de Meloidogyne incognita de raízes de cafeeiros. Fitopatologia Brasileira, $6,553$.

Carneiro, R. M. D. G., \& Almeida, M. R. A. (2001). Técnica de eletroforese usada no estudo de enzimas dos nematoides de galhas para identificação de espécie. Nematologia Brasileira, 25, 35-44.

Carneiro, R. M. D. G., \& Cofcewicz, E. T. (2008). The taxonomy of Meloidogyne spp. from coffee. In R. M. Souza (Ed.), Plant parasitic nematodes of coffee (pp. 87-122). New York: APS Press \& Springer.

Carneiro, R. M. D. G., Tigano, M. S., Randig, O., Almeida, M. R. A., \& Sarah, J. L. (2004). Identification and genetic diversity of Meloidogyne spp. (Tylenchida: Meloidogynidae) on coffee from Brazil, Central America and Hawaii. Nematology, 6, 287-298.

Carneiro, R. M. D. G., Dos Santos, M. F. A., Almeida, M. R. A., Mota, F. C., Gomes, A. C. M. M., \& Tigano, M. S. (2008). Diversity of Meloidogyne arenaria using morphological, cytological and molecular approaches. Nematology, 10, 819-834.

Castagnone-Sereno, P. (2002). Genetic variability of nematodes: a threat to the durability of plant resistance genes? Euphytica, 124, 193-199.

Castagnone-Sereno, P., Piotte, C., Abad, P., Bongiovanni, M., \& Dalmasso, A. (1991). Isolation of a repeated DNA probe showing polymorphism among populations. Journal of Nematology, 23, 316-320.

Castagnone-Sereno, P., Piotte, C., Uijthof, J., Abad, P., Wajnberg, E., Wanlerberghe-Massutti, F., et al. (1993). Phylogenetics relationships between amphimitic and partenogenetic nematodes of the genus Meloidogyne as inferred from repetitive DNA analysis. Heredity, 70, 195-204.

Castagnone-Sereno, P., Wanlerberghe-Massutti, F., \& Leroy, F. (1994). Genetic polymorphism between and within Meloidogyne species detected with RAPD markers. Genome, 37, 904-909.

Castagnone-Sereno, P., Bongiovanni, M., \& Wajnberg, E. (2007). Selection and parasite evolution: a reproductive fitness cost associated with virulence in the parthenogenetic nematode Meloidogyne incognita. Evolutionary Ecology, 21, 259-270.

Castro, J. M. C., Lima, R. D. D., \& Carneiro, R. M. D. G. (2003). Variabilidade isoenzimática de populações de Meloidogyne spp. provenientes de regiões brasileiras produtoras de soja. Nematologia Brasileira, 27, 1-12.

Cenis, J. L. (1993). Identification of four major Meloidogyne spp. by random amplified polymorphic DNA (RAPD-PCR). Phytopathology, 83, 76-80.

Cofcewicz, E. T., Carneiro, R. M. D. G., Randig, O., Chabrier, C., \& Quénéhervé, P. (2005). Diversity of Meloidogyne spp. on Musa in Martinique, Guadeloupe and French Guiana. Journal of Nematology, 37, 313-322.

Currant, J., McClure, M. A., \& Webster, J. M. (1986). Genotypic differentiation of Meloidogyne populations by detection of restiction fragment length difference in total DNA. Journal of Nematology, 18, 83-86.

Davis, R. F., \& Kemerait, R. C. (2009). The multi-year effects of repeatedly growing cotton with moderate resistance to Meloidogyne incognita. Journal of Nematology, 41, 140-145.

Elliott, C. L., Lewis, S. A., \& Mueller, J. D. (1998). Galling of South Carolina Meloidogyne incognita populations on resistant cotton genotypes. In Proceedings of the 1998 Beltwide Cotton Conference (p.145). Memphis: National Cotton Council of America.

Fargette, M., Lollier, V., Phillips, M., Blok, V., \& Frutos, R. (2005). AFLP analysis of the genetic diversity of Meloidogyne chitwoodi and M. fallax, major agricultural pests. Comptes Rendus Biologies, 328, 455-462.

Fassuliotis, G. (1985). The role of the nematologists in the development of resistant cultivars. In J. N. Sasser \& C. C. Carter 
(Eds.), An advanced treatise on Meloidogyne (Vol. 1, pp. 233-240). Raleigh: North Carolina State University Graphics.

Hartman, K. M., \& Sasser, J. N. (1985). Identification of Meloidogyne species on the basis of differential host test and perineal pattern morphology. In C. C. Carter \& J. N. Sasser (Eds.), An advanced treatise on Meloidogyne (Vol. 2, pp. 6977). Raleigh: North Carolina State University Graphics.

Huelsenbeck, J. P., Bull, J. J., \& Cunningham, C. W. (1996). Combining data in phylogenetic analysis. Trends in Ecology and Evolution, 11, 152-158.

Hussey, R. S., \& Janssen, G. J. W. (2002). Root-knot nematodes: Meloidogyne species. In J. L. Starr, R. Cook, \& J. Bridge (Eds.), Plant resistance to parasitic nematodes (pp. 43-70). Wallingford: CABI International.

Ibrahim, I. K. A., \& Lewis, S. A. (1993). Pathogenicity and reproduction of Meloidogyne arenaria race 1 and 2 and M. incognita race 3 on soybean. Journal of Nematology, 23, 159-166.

Janssen, R., Barker, J., \& Gommers, F. J. (1990). Selection of virulent and avirulent lines of Globodera rostochiensis for the $\mathrm{H} 1$ resistance gene in Solanum tuberosum spp. andigena CPC 1673. Revue de Nematologie, 13, 265.

Janssen, G. J. W., Scholten, O. E., Van Norel, A., \& Hoogendoorn, J. (1998). Selection of virulence in Meloidogyne chitwoodi to resistance in the wild potato Solanum fendleri. European Journal of Plant Pathology, 104, 645-651.

Jeffers, D. P., \& Roberts, P. A. (1993). Effect of planting date and host genotype on the root-knot nematode-Fusarium wilt disease complex of cotton. Phytopathology, 83, 645-654.

Jensen, J. L., Bohonak, A. J., \& Kelley, S. T. (2005). Isolation by distance, web service. BMC Genetics, 6, 13. v.3.23 http:// ibdws.sdsu.edu/.

Jones, J. E., Dickson, J. L., Aguillar, W., Caldwell, W. D., More, S. H., Hutchinson, R. I., et al. (1990). Stoneville LA 887: a new cotton variety. Louisiana Agriculture, 33, 5.

Kirkpatrick, T. L., \& Rothrock, C. S. (2001). Compendium of cotton diseases. Minnesota: APS press.

McClure, M. A., Ellis, K. C., \& Nigh, E. L. (1974). Post-infection development and histopathology of Meloidogyne incognita in resistant cotton. Journal of Nematology, 1, 21-26.

McPherson, M. G., Jenkins, J. N., Watson, C. E., \& Jr, M. C. (2004). Inheritance of root-knot nematode resistance in M-315 RNR and M-78 RNR cotton. Journal of Cotton Science, 8, 154-161.

Moens, M., Perry, R. N., \& Starr, J. L. (2009). Meloidogyne species - a diverse group of novel and important plant parasites. In R. N. Perry, M. Moens, \& J. L. Starr (Eds.), Rootknot nematodes (pp. 1-17). Wallingford: CABI International.

Mota, F. C., Alves, G. C. S., Giband, M., Gomes, A. C. M. M., Sousa, F. R., Mattos, V. S., et al. (2013). New sources of resistance to Meloidogyne incognita race 3 in wild cotton accessions and histological characterization of the defense mechanisms. Plant Pathology, 62, 1173-1183.

Muniz, M. F. S., Campos, V. P., Castagnone-Sereno, P., Castro, J. M. C., Almeida, M. R. A., \& Carneiro, R. M. D. G. (2008). Diversity of Meloidogyne exigua (Tylenchida: Meloidogynidae) populations from coffee and rubber tree. Nematology, 10, 897-910.

Muniz, M. F. S., Campos, V. P., Moita, A. W., Gonçalves, W., Almeida, M. R. A., Sousa, F. R., et al. (2009). Reaction of coffee genotypes to different populations of Meloidogyne spp.: detection of a naturally virulent $M$. exigua population. Tropical Plant Pathology, 34, 370-378.

Netscher, C. (1977). Observation and preliminary studies on the occurrence of resistance - breaking biotypes of Meloidogyne spp. on tomato. Cahier ORSTOM Series Biologie, 11, 173178.

Ogallo, J. L., Goodell, P. B., Eckert, J., \& Roberts, P. A. (1997). Evaluation of NemX, a new cultivar of cotton with high resistance to Meloidogyne incognita. Journal of Nematology, 29, 531-537.

Oostenbrink, M. (1966). Major characteristics of the relation between nematodes and plants. Mededelingen Landbouwhogeschool Wageningen, 66, 4.

Randig, O., Bongiovanni, M., Carneiro, R. M. D. G., \& Castagnone-Sereno, P. (2002). Genetic diversity of rootknot nematodes from Brazil and development of SCAR markers specific for the coffee-damaging species. Genome, $45,862-870$.

Riggs, R. D., \& Winstead, N. N. (1959). Studies on resistance in tomato to root-knot nematodes and on the occurrence of pathogenic biotypes. Phytopathology, 49, 716-724.

Roberts, P. A. (1992). Current status of the availability, development, and use of host plant resistance to nematodes. Journal of Nematology, 24, 213-227.

Roberts, P. A. (1995). Conceptual and practical aspects of variability in root-knot nematodes related to host plant resistance. Annual Review of Phytopathology, 33, 199-221.

Roberts, P. A., \& Thomason, I. J. (1989). A review of variability in four Meloidogyne spp. measured by reproduction on several hosts including Lycopersicon. In G. E. Russell (Ed.), Genetical and biochemical aspects of invertebrate crop pests (pp. 269-296). Hampshire: Intercept Andover.

Roberts, P. A., Frate, C. A., Mathews, W. C., \& Osterli, P. P. (1995). Interaction of virulent Meloidogyne incognita and Fusarium wilt on resistant cowpea genotypes. Phytopathology, 85, 1288-1295.

Robinson, M. R., Jenkins, J. N., \& McCarty Jr, J. C. (1997). Different sources of root-knot nematode resistance. In Proceeding of Beltwide Cotton Reseach Conferences. Memphis: National Cotton Council.

Robinson, A. F., Bowman, D. T., Cook, C. G., Jenkins, J. N., Jones, J. E., May, L. O., et al. (2001). Nematode resistance. In T. L. Kirkpatrick \& C. S. Rothrock (Eds.), Compendium of cotton diseases (pp. 68-72). Saint Paul: APS Press.

Ruano, O., Carneiro, R. G., Brito, J. A., Silva, J. F., \& Juliatti, F. C. (1997). Algodão (Gossypium hirsutum)—Doenças causadas por nematoides. In F. X. R. Vale \& L. Zambolim (Eds.), Controle de doenças de plantas- grandes culturas (pp. 583-603). Viçosa: Editora UFV.

Santos, M. F. A., Furlanetto, C., Almeida, M. R. A., Carneiro, M. D. G., Mota, F. C., Mendes, A. C. M., et al. (2012). Biometrical, biological, biochemical and molecular characteristics of Meloidogyne incognita isolates and related species. European Journal of Plant Pathology, 134, 671-684.

Semblat, J. P., Wajnberg, E., Dalmasso, A., Abad, P., \& Castagnone-Sereno, P. (1998). High-resolution DNA fingerprinting of parthenogenetic root-knot nematodes using AFLP analysis. Molecular Ecology, 7, 119-125.

Starr, J. L., \& Mercer, C. F. (2009). Development of resistant varieties. In R. N. Perry, M. Moens, \& J. L. Starr (Eds.), 
Root-knot nematodes (pp. 326-337). Wallingford: CABI International.

Starr, J. L., Carneiro, R. G., \& Ruano, O. (2005). Nematodes parasites of cotton and other tropical fiber crops. In M. Luc, R. A. Sikora, \& J. Bridge (Eds.), Plant parasitic nematodes in subtropical and tropical agriculture (pp. 733-750). Wallingford: CABI International.

Starr, J. L., Moresco, E. R., Smith, C. W., Nichols, R. L., Roberts, P. A., \& Chee, P. (2010). Inheritance of resistance to Meloidogyne incognita in primitive cotton accessions from Mexico. Journal of Nematology, 42, 352-358.

Suazo, A., \& Hall, H. G. (1999). Modification of the AFLP protocol applied to honey bee (Apis mellifera L.) DNA. BioTechniques, 26, 704-709.
Swofford, D. L. (2002). PAUP*. Phylogenetic analysis using parsimony (*and other methods). Sunderland: Sinauer Associates.

Triantaphyllou, A. C. (1985). Cytogenetics, cytotaxonomy and phylogeny of root-knot nematodes. In C. C. Carter \& J. N. Sasser (Eds.), An advanced treatise on Meloidogyne, vol. 1, biology and control (pp. 113-126). Raleigh: North Carolina State University Graphics.

Veech, J. A., \& Starr, J. L. (1986). Comparison of development reproduction and aggressiveness of Meloidogyne incognita race 3 and 4 on cotton. Journal of Nematology, 18, 413-415.

Zhou, E., Wheeler, T. A., \& Starr, J. L. (2000). Root galling and reproduction of Meloidogyne incognita isolates from Texas on resistant cotton genotypes. Journal of Nematology, 32, 513-518. 